\title{
New occurrences of Botryosphaeriaceae causing black root rot of cassava in Brazil
}

\author{
Alexandre R. Machado' ${ }^{1}$ Danilo B. Pinho ${ }^{1}$, Saulo A. S. de Oliveira $^{2}$ \& Olinto L. Pereira $^{1}$ \\ ${ }^{1}$ Departamento de Fitopatologia, Universidade Federal de Viçosa, 36570-900, Viçosa, MG, Brazil; ${ }^{2}$ Embrapa Mandioca e \\ Fruticultura, 44380-000, Cruz das Almas, BA, Brazil
}

Author for correspondence: Olinto L. Pereira, e-mail: oliparini@ufv.br

\begin{abstract}
Despite the occurrence of several diseases of cassava, the cassava black root rot (CBR) represents one of the main limiting factor for crop rentability in the world. However, the etiology of CBR is complex and it needs to be revised based on current molecular analysis. On this work, molecular and morphological studies allowed for the identification of three species of Botryosphaeriaceae causing black root rot disease of cassava in the states of Maranhão and Paraíba, Brazil, namely: Lasiodiplodia euphorbicola, Lasiodiplodia pseudotheobromae and Neoscytalidium hyalinum. This is the first report of these three fungal species as causal agents of CBR in the world.

Key words: Lasiodiplodia spp., Manihot esculenta, Neoscytalidium hyalinum, Botryosphaeriales, Dothideomycetes, soilborne fungi.
\end{abstract}

Cassava (Manihot esculenta Crantz) is an important food source. Its tuberous edible roots are high in calories and are a source of starch, the major form of carbohydrate consumed in the tropics for human and animal nutrition (Adeoti, 2010; CEPLAC, 2013). Furthermore, it tolerates adverse climatic and edaphic conditions and requires little care (Nweke et al., 2002). Due to these characteristics, cassava is an important activity for smallholders and it is widely cultivated in developing countries to reduce famine, providing a major source of nutrition for over 500 million people (FAO, 2013).

Currently, cassava productivity in Brazil, one of the probable centers of origin of cassava, is low. Cassava cultivation by family stallholders utilize low-level of technologies, including manivas (propagation materials) of poor physiological and phytosanitary quality (Silva et al., 2013). The high occurrence of disease transmitted by propagation material is one of the main factors that contribute to lower cassava productivity in Brazil (Cavalcante, 2001).

Some of these disease transmitted by propagative materials also occur in the postharvest phase. Among these is root rot, which is the main limiting factor for the production of cassava because it directly affects the marketable product. In Brazil numerous root rot fungi are listed as associated with cassava, namely: Fusarium solani (Mart.) Sacc., Phytophthora capsici Leonian, P. drechsleri Tucker, P. nicotianae var. parasitica (Dastur) G.M. Waterh., $P$. richardiae Buisman, Scytalidium lignicola Pesante, Rhizoctonia solani J.G. Kühn, Rosellinia necatrix Berl. ex Prill., and some Botryosphaeriaceae as Diplodia manihotis Sacc. and Lasiodiplodia theobromae (Pat.) Griffon \&
Maubl. (Mendes and Urben, 2014). However, among these agents, only Scytalidium lignicola is considered to be the causal agent of cassava black root rot (CBR) (Laranjeira et al., 1994; Poltronieri et al., 1998; Muniz et al., 1999; Serra et al., 2009; Silva et al., 2013). It causes severe yield losses (Silva et al., 2013).

Nevertheless, the status of Scytalidium lignicola as the causal agent of CBR in Brazil needs to be revised based on molecular analysis. Recently, several species previously identified as Scytalidium were transferred to the genus Neoscytalidium (Seifert et al., 2011). Neoscytalidium is morphologically similar to Scytalidium, but under certain conditions this fungus forms synnanamorphs having pycnidia which contain Fusicoccum-like conidia. Moreover, these two genera belong to different orders of Ascomycota (Crous et al., 2006; Seifert et al., 2011; Phillips et al., 2013). Therefore, the identification of these fungi only by morphological characters can lead to errors. A morphological and molecular approach is required for a more accurate identification of the fungi associated with CBR (Hyde et al., 2010; Cai et al., 2011a; 2011b).

In 2011, six fungal isolates from cassava plants with symptoms of CBR collected in the states of Maranhão and Paraíba were initially identified as Scytalidium sp. and Lasiodiplodia sp. based upon morphological characteristics. Later, these isolates were provided by Embrapa Mandioca e Fruticultura to the Laboratório de Patologia de Sementes e de Pós-Colheita of the Universidade Federal de Viçosa for taxonomical and molecular studies. The aim of the present study was to identify these isolates based on morphological characters and molecular analysis and to verify their pathogenicity. 
The isolates were grown on Petri dishes containing $2 \%$ water-agar (WA) overlaid with double-sterilized twigs of Pinus and incubated at $25^{\circ} \mathrm{C}$ with a photoperiod of $12 \mathrm{~h}$ to induce the formation of fruiting bodies and sporulation. The single-spore derived cultures were deposited in the Coleção de Culturas de Fungos Fitopatogênicos "Prof. Maria Menezes" (CMM) at the Universidade Federal Rural de Pernambuco, Brazil. Sections of the fruiting bodies were prepared and mounted in lactophenol. Thirty measurements of conidia, paraphyses and conidiogenous cells were made with an Olympus CX31 light microscope. Images were obtained with an Olympus BX 51 light microscope fitted with a digital camera (Olympus EVOLT330).

Genomic DNA was extracted from colonies grown on PDA at $25^{\circ} \mathrm{C}$ for one week. Approximately $40 \mathrm{mg}$ of mycelia were collected. Extraction was carried out through a process involving freezing the samples with liquid nitrogen and grinding them into a fine powder using a microcentrifuge tube pestle. The crushing was resumed after adding $100 \mu \mathrm{L}$ of Nuclei Lysis Solution of the Wizard Genomic DNA Purification kit (Promega). Extraction continued as described by Pinho et al. (2012). PCR reagents, primers and conditions were as described by Machado et al. (2014). PCR products were directly sequenced at Macrogen (South Korea).

Nucleotide sequences were edited with the BioEdit software (Hall, 2012). All sequences were checked manually and positions with ambiguous nucleotides were clarified using sequences from both DNA strands. New sequences were deposited in GenBank (see Table 1 for accession numbers). Sequences of internal transcribed spacer regions 1 and 2 including the 5.8S rRNA gene (ITS), translation elongation factor $1-\alpha(\mathrm{TEF} 1-\alpha)$ and $\beta$-tubulin ( $\beta \mathrm{t}$ ) of additional species were retrieved from GenBank (Table 1). Consensus sequences were compared against GenBank's database using the MegaBLAST algorithm. The closest hit sequences were aligned using MUSCLE (Edgar, 2004) implemented in MEGA v. 5 (Tamura et al., 2011). Alignments were checked visually, and manual adjustments were made when necessary. Ambiguously aligned sequences within the dataset were excluded from the analysis. The resulting alignment was deposited into TreeBASE (www. treebase.org) under accession number S15379. Phylogenetic analyses were conducted as described by Machado et al. (2014). The models of evolution selected according to the Akaike Information Criterion (AIC) were GTR+I for ITS, $\mathrm{HKY}+\mathrm{G}$ for TEF and $\mathrm{GTR}+\mathrm{G}$ for $\beta \mathrm{t}$ and the tree was rooted to Spencermartinsia viticola CBS117009.

Pathogenicity one representative isolate of each species was tested. Each selected isolate was grown in a Petri dish with PDA for 7 days at $25^{\circ} \mathrm{C}$. Roots that were approximately $20 \mathrm{~cm} \times 7 \mathrm{~cm}$ wide had their bark wounded superficially with a scalpel on the inoculation site. Six $\mathrm{mm}$ diam culture disks obtained from the margins of the growing culture were placed on the wounds. Wounded roots on which PDA plugs were deposited served as controls. Five roots were inoculated with each isolate and placed in plastic boxes that contained a portion of moistened cotton wool and were maintained in a moist chamber at approximately $25^{\circ} \mathrm{C}$ for two weeks.

Phylogenetic analysis (Figure 1) and morphological comparisons (Table 2) revealed three distinct species of Botryosphaeriaceae in association with CBR among the six fungal isolates: Lasiodiplodia euphorbicola A.R. Machado \& O.L. Pereira (Figure 2H-K), L. pseudotheobromae A.J.L. Phillips, A. Alves \& Crous (Figure 2L-O) and Neoscytalidium hyalinum (C.K. Campb. \& J.L. Mulder) A.J.L. Phillips, Groenewald \& Crous (Figure 2C-G).

In recent years, morphological and molecular analyses have revealed a great diversity of species within plant pathogenic Botryosphaeriaceae (Begoude et al., 2010; Mehl et al., 2011; Ismail et al., 2012; Urbez-Torres et al., 2012; Marques et al., 2013a; 2013b; Machado et al., 2014). Despite the usefulness of morphological characters, molecular analysis became essential for recognizing taxa that are included in species complexes, such as Lasiodiplodia (Alves et al., 2008; Abdollahzadeh et al., 2010; Ismail et al., 2012; Urbez-Torres et al., 2012; Marques et al., 2013a). Molecular analysis can also distinguish taxa that show similar morphologies but are phylogenetically distant, such as the genera Neocytalidium and Scytalidium, which belong to Botryosphaeriaceae and Helotiaceae, respectively (Crous et al., 2006; Seifert et al., 2011; Phillips et al., 2013). Similarly, molecular analysis in this study revealed that two species of Lasiodiplodia are associated with CBR, and demonstrated that the Scytalidium-like fungus that causes this disease belongs to Neoscytalidium. Thus, it is possible that previous reports of fungi causing CBR in Brazil (Laranjeira et al., 1994; Poltronieri et al., 1998; Muniz et al., 1999; Serra et al., 2009; Silva et al., 2013) were misidentified as Scytalidium lignicola.

The species Neoscytalidium hyalinum $\quad(=N$. dimidiatum) is a botryosphaeriaceous fungus that, under special conditions, forms Scytalidium-like and Fusicoccumlike synnanamorphs (Crous et al., 2006; Phillips et al., 2013). This is probably the main reason for the misidentification of this pathogen, which is often confused with the hyphomycete fungus Scytalidium. Therefore, it is clear that the identification of the etiologic agent of CBR requires a careful polyphasic approach.

Pathogenicity of the isolates representing the three species was confirmed two weeks after inoculation. All inoculated roots showed symptoms that were similar to those observed in the field, with the subsequent emergence of fungal structures occurring externally on the bark (Figure 2A). From the lesions, it was possible retrieve each of the inoculated fungi. Symptoms were not observed in control roots (Figure 2B).

Diseases caused by Neoscytalidium hyalinum tend to be more common in tropical countries (Phillips et al., 2013). In Brazil, this species was previously reported on Jatropha curcas L. and Mangifera indica L. (Machado 
A.R. Machado et al.

TABLE 1 - Genbank accession numbers of DNA sequences of Botryosphaeriaceae used in phylogenetic analysis. The specimens obtained in this study are highlighted in bold.

\begin{tabular}{|c|c|c|c|c|c|}
\hline \multirow[t]{2}{*}{ Species } & \multirow[t]{2}{*}{ Isolates } & \multirow[t]{2}{*}{ Host/Substrate } & \multicolumn{3}{|c|}{ Genbank accession no. } \\
\hline & & & ITS & EF1- $\alpha$ & $\beta \mathbf{t}$ \\
\hline Neoscytalidium hyalinum & CBS 499.66 & Mangifera indica & AY819727 & EU144063 & FM2111671 \\
\hline N. hyalinum & PD104 & Ficus carica & GU251107 & GU251239 & GU251767 \\
\hline N. hyalinum & CMM4022 & Manihot esculenta & KF369269 & KF553902 & KF720790 \\
\hline N. hyalinum & CMM3895 & M. esculenta & KF369265 & KF553898 & KF720786 \\
\hline N. novaehollandiae & CBS122072 & Adansonia gibbosa & EF585535 & EF585581 & - \\
\hline N. novaehollandiae & CBS122610 & Acacia synchronicia & EF585536 & EF585578 & - \\
\hline Lasiodiplodia venezuelensis & WAC12539 & Acacia mangium & DQ103547 & DQ103568 & - \\
\hline L. venezuelensis & CMW13513 & Acacia mangium & DQ103549 & DQ103570 & - \\
\hline L. rubropurpurea & WAC12536 & Eucalyptus grandis & DQ103554 & DQ103572 & - \\
\hline L. gonubiensis & CBS115812 & Syzygium cordatum & DQ458892 & DQ458877 & DQ458860 \\
\hline L. crassispora & CBS110492 & Unknown & EF622086 & EF622066 & EU673134 \\
\hline L. crassispora & CMW22653 & Pterocarpus angolensis & FJ888465 & FJ888452 & - \\
\hline L. margaritacea & CBS122519 & Adansonia gibbosa & EU144050 & EU144065 & - \\
\hline L. pseudotheobromae & CBS116459 & Gmelina arborea & EF622077 & EF622057 & EU673111 \\
\hline L. pseudotheobromae & CMM3887 & Jatropha curcas & KF234559 & KF226722 & KF254943 \\
\hline L. pseudotheobromae & СММ3894 & M. esculenta & KF369264 & KJ452244 & - \\
\hline L. parva & CBS456.78 & Cassava-field soil & EF622083 & EF622063 & - \\
\hline L. parva & CBS495.78 & Cassava-field soil & EF622085 & EF622065 & - \\
\hline L. euphorbicola & CMM3651 & Jatropha curcas & KF234553 & KF226711 & KF254937 \\
\hline L. euphorbicola & CMM3652 & Jatropha curcas & KF234554 & KF226715 & KF254938 \\
\hline L. euphorbicola & CMM3609 & Jatropha curcas & KF234543 & KF226689 & KF254926 \\
\hline L. euphorbicola & CMM4018 & Manihot esculenta & KF369268 & KF553901 & KF720789 \\
\hline L. euphorbicola & СММ3973 & Manihot esculenta & KF369267 & KF553900 & KF720788 \\
\hline L. euphorbicola & CMM3897 & Manihot esculenta & KF369266 & KF553899 & KF720787 \\
\hline L. citricola & IRAN1521C & Citrus sp. & GU945353 & GU945339 & - \\
\hline L. citricola & IRAN1522C & Citrus sp. & GU945354 & GU945340 & - \\
\hline L. egyptiacae & CBS130992 & Mangifera indica & JN814397 & JN814424 & - \\
\hline L. egyptiacae & BOT-29 & Mangifera indica & JN814401 & JN814428 & - \\
\hline L. hormozganensis & IRAN1500C & Olea sp. & GU945355 & GU945343 & - \\
\hline L. hormozganensis & IRAN1498C & Mangifera indica & GU945356 & GU945344 & - \\
\hline L. subglobosa & CMM3872 & Jatropha curcas & KF234558 & KF226721 & KF254942 \\
\hline L. subglobosa & CMM4046 & Jatropha curcas & KF234560 & KF226723 & KF254944 \\
\hline L. macrospora & CMM3833 & Jatropha curcas & KF234557 & KF226718 & KF254941 \\
\hline L. plurivora & STE-U5803 & Vitis vinifera & EF445362 & EF445395 & - \\
\hline L. gilanensis & IRAN1523C & Unknown & GU945351 & GU945342 & - \\
\hline L. gilanensis & IRAN1501C & Unknown & GU945352 & GU945341 & - \\
\hline L. iraniensis & IRAN1517C & Citrus sp. & GU945349 & GU945337 & - \\
\hline L. iraniensis & IRAN1519C & Mangifera indica & GU945350 & GU945338 & - \\
\hline L. brasiliense & CMM4015 & Mangifera indica & JX464063 & JX464049 & - \\
\hline L. brasiliense & CMM2186 & Carica papaya & KC484812 & KC481542 & - \\
\hline L. brasiliense & CMM2255 & Carica papaya & KC484792 & KC481523 & - \\
\hline L. brasiliense & CMM2313 & Carica papaya & KC484793 & KC481524 & - \\
\hline L. jatrophicola & CMM3610 & Jatropha curcas & KF234544 & KF226690 & KF254927 \\
\hline L. mahajangana & CMW27801 & Terminalia catappa & FJ900595 & FJ900641 & FJ900630 \\
\hline L. mahajangana & CMW27820 & Terminalia catappa & FJ900597 & FJ900643 & FJ900632 \\
\hline L. theobromae & CMW28571 & Terminalia ivorensis & GQ469924 & GQ469897 & - \\
\hline Botryosphaeria rhodina & CBS164.96 & Unknown & AY 640255 & AY 640258 & EU673110 \\
\hline B. rhodina & CBS124.13 & Unknown & DQ458890 & DQ458875 & DQ458858 \\
\hline L. theobromae & CBS111530 & Unknown & EF622074 & EF622054 & - \\
\hline B. rhodina & CMW9074 & Pinus sp. & AY236952 & AY236901 & AY236930 \\
\hline L. viticola & UCD2553AR & Vitis vinifera & HQ288227 & HQ288269 & HQ288306 \\
\hline L. viticola & UCD2604MO & Vitis vinifera & HQ288228 & HQ288270 & HQ288307 \\
\hline L. missouriana & UCD2193MO & Vitis vinifera & HQ288225 & HQ288267 & HQ288304 \\
\hline L. missouriana & UCD2199MO & Vitis vinifera & HQ288226 & HQ288268 & HQ288305 \\
\hline Spencermartinsia viticola & CBS117009 & Vitis vinifera & AY905554 & AY905559 & EU673104 \\
\hline
\end{tabular}




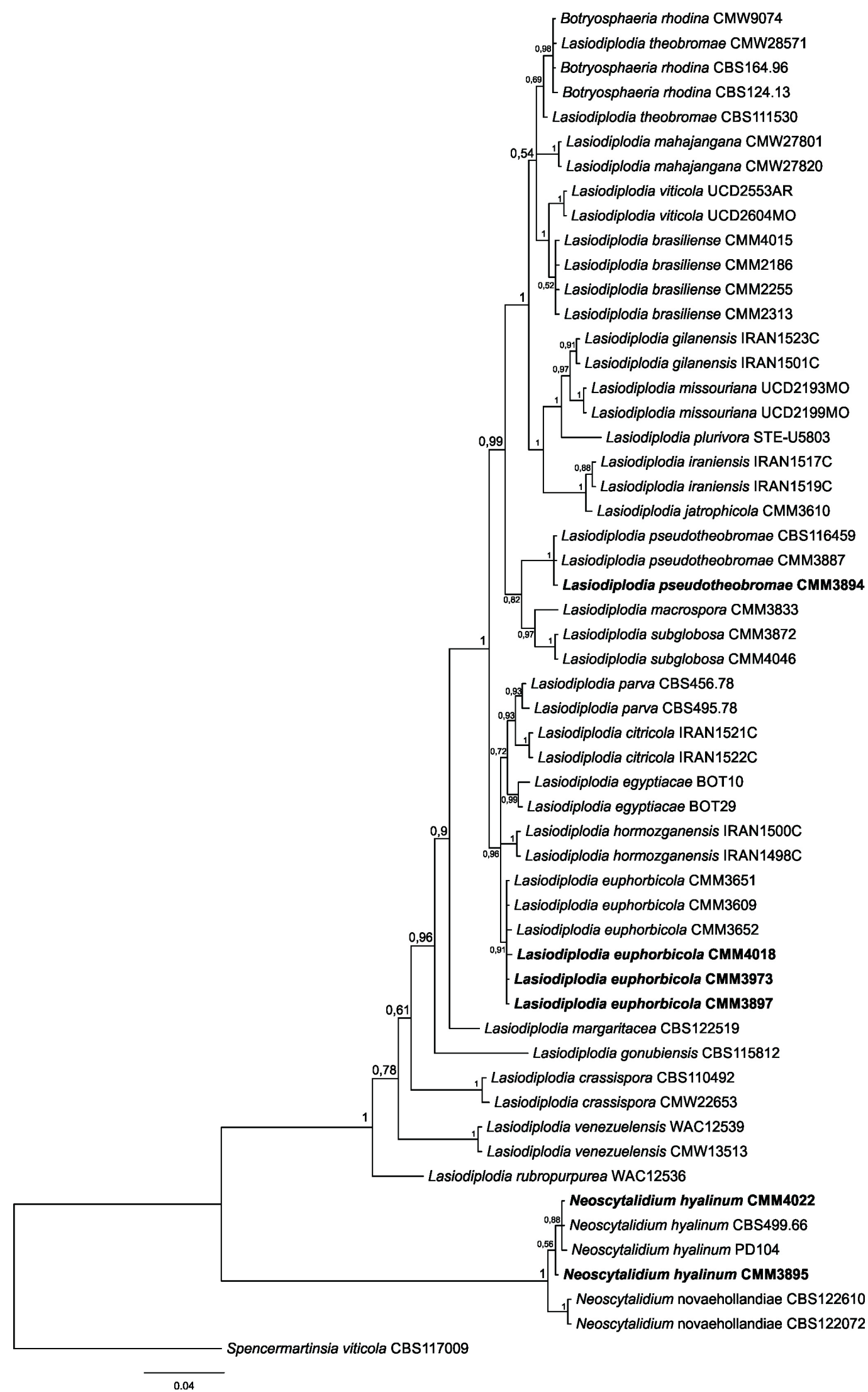

FIGURE 1 - Multilocus phylogenetic tree inferred from Bayesian analysis based on the combined sequences of the ITS, TEF- $1 \alpha$ and $\beta$ t genes. Bayesian posterior probabilities are indicated above the nodes. The tree was rooted to Spencermartinsia viticola CBS117009. Isolates characterized in this study are highlighted in bold. 
TABLE 2 - Biometric data of Lasiodiplodia spp. and Neoscytalidium spp. examined in this and in previous studies.

\begin{tabular}{lcccc}
\hline \hline Species & Conidia $(\boldsymbol{\mu m})$ & Paraphyses $(\boldsymbol{\mu m})$ & Conidiogenous cells $(\boldsymbol{\mu m})$ & Reference \\
\hline L. theobromae & $21-31 \times 13-15.5$ & $55 \times 3-4$ & - & Alves et al., 2008 \\
L. pseudotheobromae & $23.5-32 \times 14-18$ & $58 \times 3-4$ & 7 Alves et al., 2008 & This study \\
& $16-26 \times 10-12$ & $75 \times 3-4$ & $7-10 \times 3-4$ & Machado et al., 2014 \\
L. euphorbicola & $15-23 \times 9-12$ & $76 \times 2-4$ & $5-15 \times 3-4$ & This study \\
& $17-24 \times 10-12$ & $40 \times 2-3$ & $5-12 \times 2-3$ & Reference \\
\hline Species & Conidia $(\boldsymbol{\mu m})$ & Arthroconidia $(\boldsymbol{\mu m})$ & Conidiogenous cells $(\boldsymbol{\mu m})$ & Phillips et al., 2013 \\
\hline N. hyalinum & $10-16(-21) \times 3.5-6.5$ & $4-16.5 \times 8.5$ & $6.5-14 \times 2.5-4$ & Machado et al., 2014 \\
& $8-12 \times 4-5$ & $4-12 \times 2.5-8$ & $6-10 \times 1.5-2.5$ & This study \\
N. novaehollandiae & $5-12 \times 3-5$ & $6-12 \times 3-6$ & $7-10 \times 2-3$ & Pavlic et al., 2008 \\
\hline
\end{tabular}
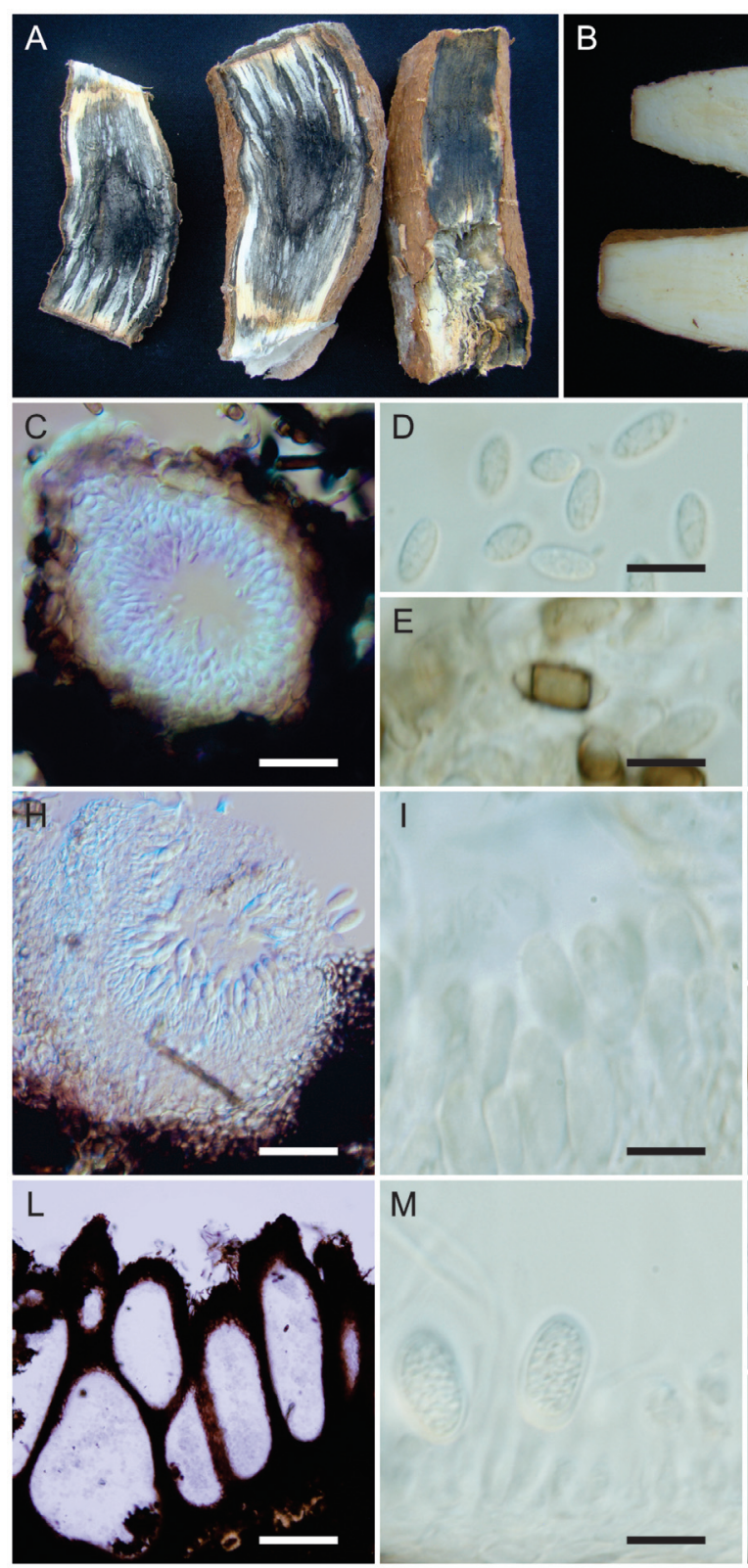
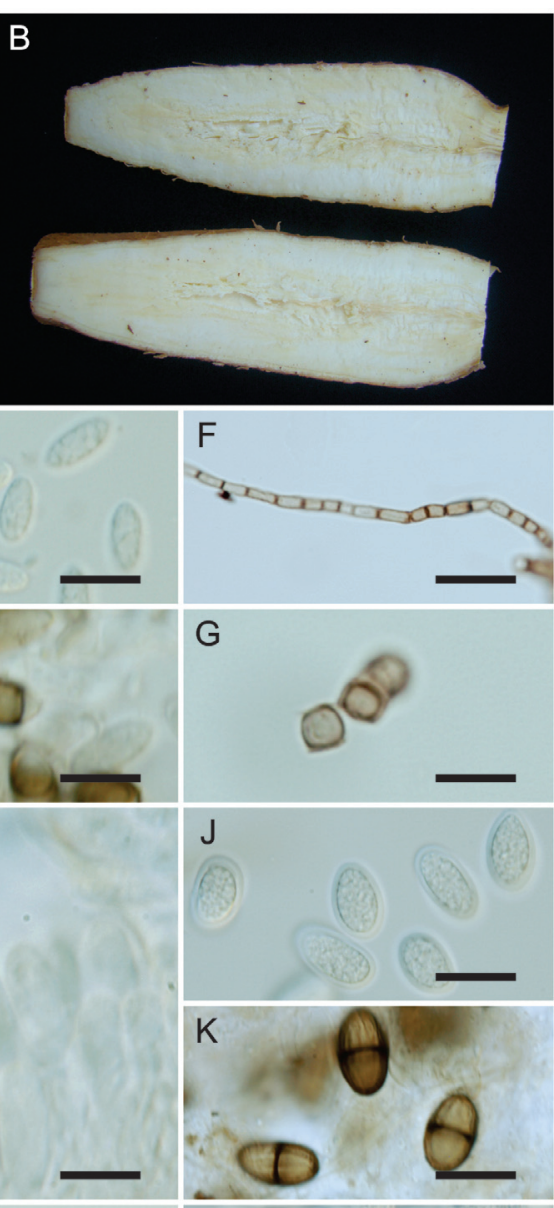

M

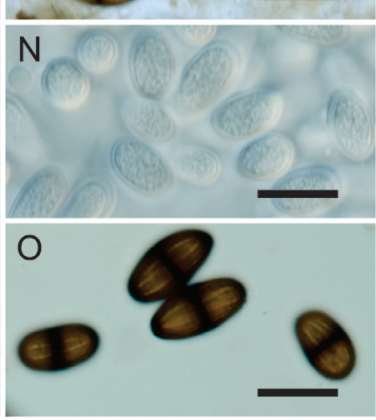

FIGURE 2 - Botryosphaeriaceae species causing black root rot of cassava. A. Symptoms of black root rot produced for Botryosphaeriaceae species in pathogenicity tests; B. Asymptomatic root used as control in pathogenicity tests; C-G. Neoscytalidium hyalinum. C. Conidiomata; D, E. Hyaline and septate mature conidia; F, G. Arthroconidia; H-K. Lasiodiplodia euphorbicola. H. Section of a conidiomata formed on Pinus twigs; I. Conidiogenous cells; J, K. Immature and mature pigmented conidia with longitudinal striations; L-O. Lasiodiplodia pseudotheobromae. L. Section of multilocular conidiomata formed on the host surface; M. Conidiogenous cells; $\mathbf{N}$, O. Immature and mature pigmented conidia with longitudinal striations. Scale bars: $\mathrm{C}, \mathrm{H}, \mathrm{L}=100 \mu \mathrm{m}$; I, J, K, M = 15 $\mu \mathrm{m} ; \mathrm{N}, \mathrm{O}=20 \mu \mathrm{m}$. 
et al., 2012; 2014; Marques et al., 2013b). Lasiodiplodia pseudotheobromae has been described in Carica papaya L., Jatropha curcas and Mangifera indica (Marques et al., 2013a; Machado et al., 2014; Netto et al., 2014), whereas L. euphorbicola was reported only on Jatropha curcas and Carica papaya (Machado et al., 2014; Netto et al., 2014). This is the first report of the occurrence of L. euphorbicola, L. pseudotheobromae and $N$. hyalinum on cassava.

Since black rot is a major limiting factor for cassava production in Brazil, the correct identification of the associated pathogen(s) is essential for future studies of disease management and for the selection of resistant varieties, and provides new and relevant information for quarantine programs.

\section{ACKNOWLEDGMENTS}

The authors thank Conselho Nacional de Desenvolvimento Científico e Tecnológico - CNPq, Coordenação de Aperfeiçoamento de Pessoal de Nível Superior - CAPES and Fundação de Amparo a Pesquisa do Estado de Minas Gerais - FAPEMIG for financial support.

\section{REFERENCES}

Abdollahzadeh J, Javadi A, Mohammadi-Goltapeh E, Zare R, Phillips AJL (2010) Phylogeny and morphology of four new species of Lasiodiplodia from Iran. Persoonia 25:1-10.

Adeoti O (2010) Water use impact of ethanol at a gasoline substitution ratio of $5 \%$ from cassava in Nigeria. Biomass and Bioenergy 34:985-992.

Alves A, Crous PW, Correia A, Phillips AJL (2008) Morphological and molecular data reveal cryptic species in Lasiodiplodia theobromae. Fungal Diversity 28:1-13.

Begoude BAD, Slippers B, Wingfield MJ, Roux J (2010) Botryosphaeriaceae associated with Terminalia catappa in Cameroon, South Africa and Madagascar. Mycological Progress 9:101-123.

Cai L, Giraud T, Zhang N, Begerow D, Cai G, Shivas RG (2011a) The evolution of species concepts and species recognition criteria in plant pathogenic fungi. Fungal Diversity 50:121-133.

Cai L, Udayanga D, Manamgoda DS, Maharachchikumbura SSN, McKenzie EHC, Guo LD, Liu XZ, Bahkali A, Hyde KD (2011b) The need to carry out re-inventory of plant pathogenic fungi. Tropical Plant Pathology 36:205-213.

CEPLAC (2013) Mandioca. Available at: www.ceplac.gov.br/ radar/Mandioca.htm. Accessed on September 12, 2013.

Cavalcante J (2001) Material de plantio de mandioca no semiárido. Circular Técnica no. 60. Petrolina, PE, Brazil. MAPA, Embrapa.

Crous PW, Slippers B, Wingfield MJ, Rheeder J, Marasas WFO, Phillips AJL, Alves A, Burgess T, Barber P, Groenewald JZ (2006) Phylogenetic lineages in the Botryosphaeriaceae. Studies in Mycology 55:235-253.

Edgar RC (2004) MUSCLE: multiple sequence alignment with high accuracy and high throughput. Nucleic Acids Research 32:1792-1797.

FAO (2013) Cassava processing. Available at: www.fao.org/ docrep/x5032e/x5032E00.htm\# Contents. Accessed on September $12,2013$.

Hall T (2012) BioEdit v7.0.9: Biological sequence alignment editor for Win95/98/2K/XP/7. Available at: www.mbio.ncsu.edu/ bioedit/bioedit.html. Accessed on July 15, 2012.

Hyde KD, Abd-Elsalam K, Cai L (2010) Morphology: still essential in a molecular world. Mycotaxon 114:439-451.

Ismail AM, Cirvilleri G, Polizzi G, Crous PW, Groenewald JZ, Lombard L (2012) Lasiodiplodia species associated with dieback disease of mango (Mangifera indica) in Egypt. Australasian Plant Pathology 41:649-660.

Laranjeira D, Santos EO, Mariano RLR, Barros ST (1994) Ocorrência da podridão negra da maniva e raiz da mandioca (Manihot esculenta) causada por Scytalidium lignicola no estado de Pernambuco, Brasil. Fitopatologia Brasileira 19:466-469.

Machado AR, Pinho DB, Dutra DC, Pereira OL (2012) Collar and root rot caused by Neoscytalidium dimidiatum in the biofuel plant Jatropha curcas. Plant Disease 96:1697.

Machado AR, Pinho DB, Pereira OL (2014) Phylogeny, identification and pathogenicity of the Botryosphaeriaceae associated with collar and root rot of the biofuel plant Jatropha curcas in Brazil, with a description of new species of Lasodiplodia. Fungal Diversity 67:231-247.

Marques MW, Lima NB, Morais JR MA, Barbosa MAG, Souza BO, Michereff SJ, Phillips AJL, Camara MPS (2013a) Species of Lasiodiplodia associated with mango in Brazil. Fungal Diversity 61:181-193.

Marques MW, Lima NB, Morais Jr MA, Michereff SJ, Phillips AJL, Câmara MPS (2013b) Botryosphaeria, Neofusicoccum, Neoscytalidium and Pseudofusicoccum species associated with mango in Brazil. Fungal Diversity 61:195-208.

Mehl JWM, Slippers B, Roux J, Wingfield MJ (2011) Botryosphaeriaceae associated with Pterocarpus angolensis (kiaat) in South Africa. Mycologia 103:534-553.

Mendes MAS, Urben AF (2014) Fungos relatados em plantas no Brasil, Laboratório de Quarentena Vegetal. Available at: pragawall. cenargen.embrapa.br/aiqweb/michtml/ fgbanco01.asp. Accessed on January 12, 2014.

Muniz MFS, Santiago AD, Fukuda C, Menezes M (1999) Scytalidium lignicola: patógeno da mandioca no estado de Alagoas. Summa Phytopathologica 25:156-158.

Netto MSB, Assunção IP, Lima GSA, Marques MW, Lima WG, Monteiro JHA, Balbino VQ, Michereff SJ, Phillips AJL, Câmara MPS (2014) Species of Lasiodiplodia associated with papaya stem-end rot in Brazil. Fungal Diversity 67:127-141.

Nweke FI, Spencer DSC, Lynam JK (2002) The cassava transformation: Africa's best kept secret. East Lansing, MI, USA. Michigan State University.

Pavlic D, Wingfield MJ, Barber P, Slippers B, Hardy GESJ, Burgess TI (2008) Seven new species of the Botryosphaeriaceae from baobab and other native trees in Western Australia. Mycologia 100:851-866.

Phillips AJL, Alves A, Abdollahzadeh J, Slippers B, Wingfield 
MJ, Groenewald JZ, Crous PW (2013) The Botryosphaeriaceae: genera and species known from culture. Studies in Mycology 76:51-167.

Pinho DB, Firmino AL, Pereira OL, Ferreira Junior WG (2012) An efficient protocol for DNA extraction from Meliolales and the description of Meliola centellae sp. nov. Mycotaxon 122:333345 .

Poltronieri LS, Trindade DR, Albuquerque FC, Poltronieri FC (1998) Ocorrência da podridão negra das raízes e do caule da mandioca no estado do Pará, causada por Scytalidium lignicola. Fitopatologia Brasileira 23:411.

Seifert KA, Morgan-Jones G, Gams W, Kendrick B (2011) The genera of Hyphomycetes. Utrecht, The Netherlands. CBS-KNAW Fungal Biodiversity Centre.

Serra IMRS, Silva GS, Nascimento FS, Lima LKF (2009) Scytalidium lignicola em mandioca: ocorrência no Estado do Maranhão e reação de cultivares ao patógeno. Summa Phytopathologica 35:327-328.

Silva CAD, Medeiros EV, Bezerra CB, Silva WM, Barros JA, Santos UJ (2013) Interferência da incorporação de matéria orgânica no solo no controle da podridão negra da mandioca, causada por Scytalidium lignicola. Bioscience Journal 29:18231831.

Tamura K, Peterson D, Peterson N, Stecher G, Nei M, Kumar S (2011) MEGA5: Molecular evolutionary genetics analysis using Maximum Likelihood, Evolutionary Distance, and Maximum Parsimony Methods. Molecular Biology and Evolution 28:27312739.

Urbez-Torres JR, Peduto F, Striegler RK, Urrea-Romero KE, Rupe JC, Cartwright RD, Gubler WD (2012) Characterization of fungal pathogens associated with grapevine trunk diseases in Arkansas and Missouri. Fungal Diversity 52:169-189.

TPP-2014-0052

Submitted: 13 April 2014

Revisions requested: 21 May 2014

Accepted: 2 July 2014

Section Editor: Silvaldo Felipe da Silveira 